\title{
EFFECT OF SOCIAL MEDIA ADDICTION ON ANXIETY AND THE RISK OF SOCIAL HEALTH DISASTER IN ADOLESCENTS
}

\author{
Muflih* \& Tia Amestiasih \\ Faculty of Health Sciences \\ University of Respati Yogyakarta \\ Email* : muflih1986@gmail.com/muflih@respati.ac.id
}

\begin{abstract}
Introduction: Adolescents who get social media addiction, dopamine discharges occur in their bodies that create anxious feelings that can cause problems in social behavior in schools, living quarters, and peer social environments, and even trigger criminal acts such as defamation, slander, kidnapping, and fraud. The purpose of this research was to analyze the relationship between social media addiction and anxiety and the risk of social health disasters in adolescents. Methods: This research method is quantitative analytic descriptive with a cross-sectional design. The number of research samples was 79 students from the total population of 385 one of the junior high school students in the Yogyakarta region of Indonesia. Data retrieval technique in this research uses Stratified Random Sampling technique. Data on social media addiction, anxiety and the risk of social health disaster were collected using questionnaires and analyzed by Spearman Rank Test, a numerical correlation statistical test, with SPSS 21. Results: The results showed that the mean value of the age variable was 13.91, social media addiction was 60.38, anxiety was 14.46, and the risk of social health disaster was 67.97. The results of the statistical hypothesis test obtained that there was no significant relationship between social media addiction, anxiety, and social health disaster risk variables in adolescents. Conclusions: The conclusion of this research obtained that social media access can cause negative and positive impacts. Anxiety and the risk of social health disasters events are thought to be influenced by external factors.
\end{abstract}

Keywords: Adolescents; Addiction; Social Media; Anxiety; Social Disaster.

\section{INTRODUCTION}

Social health problems in adolescents lately have become alarming. Several times the news about social health problems in adolescents publish at the media today, such as cases of violence, brawls among groups of teenagers, rape of friends, even the murder of a vehicle driver who is a teenager. These social health problems are thought to be caused by psychological conditions that are still unstable due to the feeling of anxiety and social media addiction.

This can be seen from the number of use of social media networking sites in Indonesia in 2016 has reached 132.7 million users or around $51.5 \%$ of the total Indonesian population of 256.2 million. When compared with social media users in Indonesia in 2014 amounting to 88.1 million, an increase of 44.6 million occurred within 2 years (2014-2016). The most social media users are on the island of Java with a total user of $86,339,350$ users or around $65 \%$ of the total internet users (Pratikta, 2013).

Research on social media addiction that has been linked to the effects of anxiety and psychosocial health problems has not yet been found. Even though psychosocial health problems are a concern of World Health Organization (WHO) today, which has been recognized by WHO is the result of gaming disorder (Aarseth, et al. 2017).

Various types of social media on the internet like Facebook, Patch, Instagram, WhatsApp, YouTube, and so on. The most popular and most widely used social media site by internet users is Facebook (Siswanto, 2013). Facebook's social media use in the world in 2013 reached 981,101,800 users, while at the national level it was known that Indonesia is the fourth largest Facebook user country in the world reaching 50,583,320 users (Siswatibudi, Paramastri, \& Lazuardi, 2016). Viewed from the age group, social media users are known that most users are teenagers aged $13-15$ years as much as $43 \%$ or 
around 21,830,300 users. The next most users of the 18-24 year age group were $22 \%$, then the range of $16-17$ years was $14 \%$.

The results of this study help researchers to identify the level of anxiety and social health disaster risk in adolescents as a result of social media addiction, so that recommendations can be formulated in the form of nursing care strategies that can minimize the problem. In addition, the results of this study help students to get a reference for learning in the process of community nursing care and disaster nursing in a group of youth related to social health problems. In addition, the results of this study will be a recommendation for efforts to reduce the risk of health disasters due to social conflict among adolescents.

\section{METHODS}

The type of research conducted in this research is quantitative research with comparative analytical research methods using cross sectional design to study the dynamics of differences between social media addiction, anxiety and the risk of social health disasters. The location of this study was conducted at Junior High School 3 Kalasan, Yogyakarta. This research was carried out starting in MayAugust 2018. The population in this study were all students of class VII, VIII, IX in Junior High School 3 Kalasan, Yogyakarta totaling 385 people. In this study, samples were taken 79 students who had social media users (based on Slovin formula) with inclusion criteria; 1) Students in grades VII to IX (ages 13-16 years), 2) Willing to become respondents, and 3) Students present at the time of conducting research. The exclusion criteria include; 1) Students are sick and not attending school, and 2) Students resign in the midst of research. The sampling technique in this study used the Stratified Random Sampling technique, beginning with randomized classes to take representation of age levels and minimize bias because of it. Then proceed with simple random sampling based on the list of student names obtained to get the selected sample representatives.

The variables of this study consisted of social media addiction, namely dependency behavior seen from the components: salience, mood modification, tolerance, withdrawal symptoms, conflict, and relapse (Andreassen, 2012). Other variables are anxiety seen from the components: physiological, cognitive, behavioral, and affective (Utari, 2012), and social health disaster risk which is seen from the pattern of teenagers interacting with faceto-face ways that occur between adolescents in their social environment both at home, in the play environment and at school (Herdman \& Kamitsuru, 2014).

Data collection began with giving informed consent, then done by distributing questionnaires for the risk of social health disastersused the Social Interaction Anxiety Scale (SIAS) questionnaire adopted from Mattick \& Clarke (1998) consists of 20 question items, which was previously used by Muflih, Hamzah, \& Puniawan (2017). While the anxiety variable by adopting from Taylor Manifest Anxiety Scale (T-MAS) by Taylor (1953) consists of 28 question items and social media addiction by adopting from the questionnaire Bergen Facebook Addiction Scale (BFAS) by Andreassen (2012) consists of 18 question items. Reliability test results were 0.770 for SIAS, 0.831 for T-MAS, and 0.850 for BFAS questionnaire. Data was collected and interpreted in the form of numerical values with using Spearman Rank Test numerical correlation statistical test. This research has received approval from the research location officials.

This research has received approval from the research location officials. This research has been conducted also hold the principle of research ethics which are autonomy, anonymity, beneficence, veracity, justice and with informed consent.

\section{RESULTS}

In this study the comparison of respondents by sex was 57 percent male and 43 percent female. In table 1 , it can be seen that the variables of age, social media addiction, anxiety and the risk of social health disasters are not normally distributed ( $\mathrm{P}$ value $<0.05$ ). Age variables have a mean value of 13.91, social media addiction has a mean value of 60.38 , anxiety has a mean value of 14.46 , and the risk of social health disasters has a mean value of 67.97. 
Table 1. Distribution of tendency central of age, social media addiction, anxiety, and risk of social health disaster

\begin{tabular}{lrrrrrr}
\hline Variable & Minimum & Maximum & Mean & Median & $\begin{array}{r}\text { Std } \\
\text { Dev }\end{array}$ & $\begin{array}{c}\text { Normality } \\
\text { Test }\end{array}$ \\
\hline Age & 11.00 & 16.00 & 13.91 & 14.00 & 1.03 & 0.000 \\
Social Media Addiction & 18.00 & 86.00 & 60.38 & 65.00 & 17.12 & 0.002 \\
Anxiety & 5.00 & 24.00 & 14.46 & 14.00 & 3.14 & 0.000 \\
Risk of Social Health & 45.00 & 100.00 & 67.97 & 66.00 & 10.50 & 0.003 \\
$\quad$ Disaster & & & & & & \\
\hline
\end{tabular}

Description: ${ }^{*}$ Kolmogorov-Smirnov Test

Table 2. Correlation and $P$ value between social media addiction, anxiety and risk of social health disaster

\begin{tabular}{lccc}
\hline $\begin{array}{l}\text { Correlation test } \\
\text { Between Variables }\end{array}$ & $\begin{array}{c}\text { Social Media } \\
\text { Addiction }\end{array}$ & Anxiety & $\begin{array}{c}\text { Risk Of Disaster In } \\
\text { Social Health }\end{array}$ \\
\hline Social Media Addiction & - & $-0.038(0.742)$ & $-0.098(0.392)$ \\
Anxiety & $-0.038(0.742)$ & - & $-0.017(0.880)$ \\
Risk of Social Health Disaster & $-0.098(0.392)$ & $-0.017(0.880)$ & - \\
\hline
\end{tabular}

Description : ${ }^{*}$ Spearman Rank Test $=$ r Value $(\mathrm{P}$ value $)$

In table 2, it can be seen that there is no significant relationship between the variables of social media addiction, anxiety and the risk of social health disasters (P value> 0.05). This means that social media addiction is not related to anxiety problems or the risk of social health disasters. The calculated $r$ value shows a negative value (-). This means that different directions occur between variables. The higher the value of social media addiction, the lower the value of anxiety or the risk of social health disasters.

Figure 1. Scatter Diagram Between Social Media Addiction and Anxiety

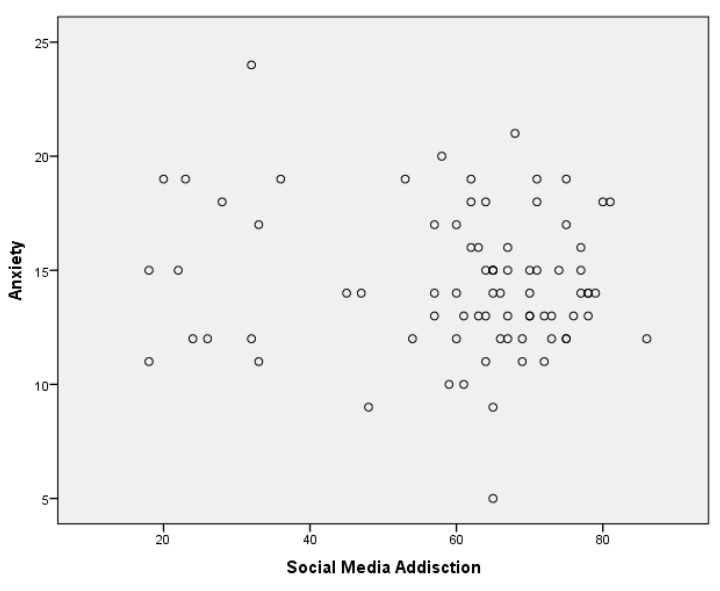

In Figure 1, it can be seen that the points on the scatter diagram are evenly distributed and do not form a particular imaginary line. This shows that the value between social media addiction and anxiety variables does not show a correlation.

Figure 2. Scatter Diagram Between Anxiety And The Risk of Social Health Disaster

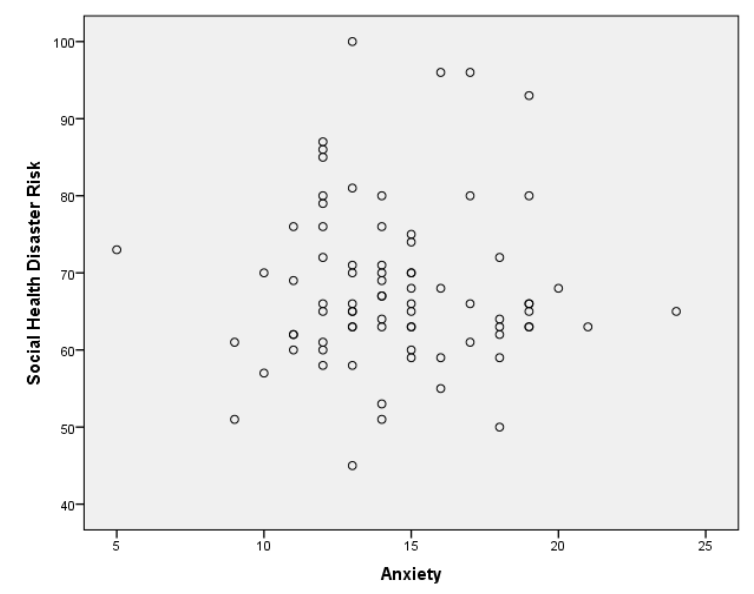

In Figure 2, it can be seen that the points on the scatter diagram are evenly distributed and do not form a particular imaginary line. This shows that the values between anxiety variables and the risk of social health disasters do not show a correlation. 
Figure 3. Scatter Diagram Between Social Media Addiction Variables And The Risk of Social Health Disaster

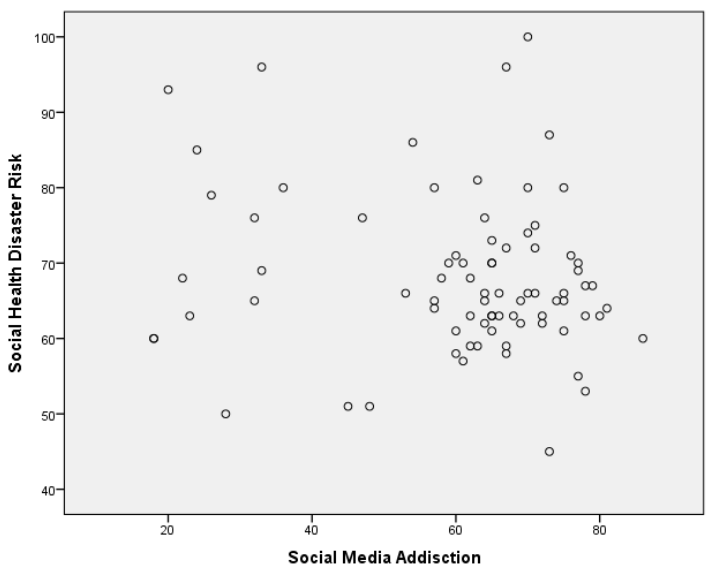

In Figure 3, it can be seen that the points on the scatter diagram are evenly distributed and do not form a particular imaginary line. This shows that the value between social media addiction and social health disaster risk variables does not show a correlation.

\section{DISCUSSIONS}

The results showed that there was no significant relationship between the meaning of social media addiction, anxiety and social health disaster risk variables. This means that the occurrence of anxiety and risk of social health disasters were not determined by social media addiction. This can be seen from table 2 that the $\mathrm{P}$ value between variables are $>0.05$ that were caused by the average value of each variable far enough from the maximum total value (see Table 1). The higher the score of the social media addiction, anxiety and risk of social health disaster variables, the higher the likelihood of addiction, anxiety, and health disorders social interactions.

In the Table 1 , the mean value of the three variables is almost the same as the median value and far from the maximum value. So that it can be concluded that in the study sample has not described the occurrence of social media addiction, anxiety, and health problems of social interaction.

This was possible because social media access do not always have a negative impact, but there are positive impacts from it. According to Widodo (2015), the positive impact of social media use on adolescents, it is easier for teens to get information more quickly, can get to know and establish communication with various people from around the world.

The Central Statistics Agency (Badan Pusat Statistik, in Indonesia) in collaboration with the Indonesian Internet Service Providers Association Stated that internet users' data based on the most visited social media content was Facebook social media content of 71.6 million users or $54 \%$.

However, there are still negative impacts from the use of social media, namely teenagers are too quickly satisfied with the knowledge gained from the real world, lack of socialization because they prefer to be alone with the game technology, and can also provide addictive effects for teenagers.

At this time, internet access that can be done with mobile devices such as smartphones, tablets, etc., allows increasing the amount of daily time exposed to the internet. In 2010 mobile internet users amounted to 38 percent (Noviyarto, 2010).

Internet usage is currently very popular because it is able to provide information that does not recognize geographical boundaries. The use of the internet is based on several motivations or reasons. According to Buente and Robbin (2008) internet use is based on 3 (three) dimensions of interest namely; Information Utility (obtaining information), Leisure/fun activities (obtaining pleasure), Communication (communicating), and Transaction (transaction of buying and selling).

According to Walker (2014), the effects of social media addiction such as Facebook are caused by two things. First, because we like to get friends and get the attention of many people. Second, because they are happy to be people who are known and recognized for their existence (Mark, et al., 2014). According to Akter's research (2014), of 233 students in America said that 55\% used social media Facebook to release personal problems and the length of time used to access Facebook social media social media was at least 4 hours/day.

As many as $84.4 \%$ among adolescents experience heavy addiction, moderate addiction $5.88 \%$, and mild addiction $2.35 \%$. Besides Facebook social media content that is often visited is Instagram 19.9 million, or $15 \%$, YouTube is 14.5 million, Gmail is 7.9 million or $6 \%$, Twitter is 7.2 million or $5.5 \%$ and linked in as many as 796 thousand or 0.6\% (Isparmo, 2016). 
The use of social media can be included in the category of dependency behavior when included in the following components (Griffiths, 2013): 1) Teenagers are busy with the use of social media, 2) The use of social media is used to escape from reality or create feelings of euphoria, 3) Behavior social media use is continued without tolerance, and 4) If social media use behavior is abstained or disturbing, there are symptoms of feeling anxious, depressed, or irritable.

For individuals who are addicted to social media when he gets a lot of notifications, automatically dopamine in the person's body reacts, and if in one day he does not get a notification then there is a feeling of anxiety due to the reaction of addiction. According to Musofa (2013), dopamine is a chemical compound in the body that can stimulate a sense of liking, joy, calm as well as when drug addicts or morphine. If in one day he does not get a notification then there is a feeling of anxiety, anxiety, and worry that causes problems in social behavior in school, residence, and social environment with peers and even lead to criminal acts such as defamation, hoax distribution, kidnapping, and fraud.

This can cause the risk of social health disasters among adolescents due to social conflicts that can threaten the lives and livelihoods of the community. According to Akter (2014), in America as many as 119 students from 233 students said $69 \%$ felt very anxious, helpless, and depressed, and $73 \%$ felt very uncomfortable if they did not use social media in a few hours.

Teenagers are very susceptible to experiencing anxiety which results in problems of social behavior in school, residence, and social environment with peers (Prawoto, 2010). This is due to adolescence as a period of human development from childhood to adulthood (Anggreni, Natosba, \& Trilia, 2015). Adolescence is part of a series of life and not a separate period that is not related to other periods (Wangi, Istianah, \& Alviani, 2015). At this time there are changes in biological, cognitive, and social-emotional (Santrock, 2007). Major changes that occur in adolescents are physical, cognitive, and psychosocial (Papalia, Old, \& Feldman, 2011).

According to Taylor (1953) \& Hawari (2008) in Utari (2012) that the signs and symptoms of anxiety include behavior, affective, cognitive, physiological, including, namely: 1) Behavior, namely: in behavior there are signs and symptoms namely agitation, anxiety, movement extra, insomnia, poor eye contact, glancing, expressing concern due to changes in life events, lurking behavior and looking alert; 2) Affective, namely: focus on yourself, distress (Rodiyah \& Praningsih, 2015), anxiety, nervousness, deep sadness, fear, gnashing of teeth, regret, sensitivity, feeling of inadequacy, despair, doubt, very worried, and happy excessive; 3) Cognitive, namely: in cognitive, signs and symptoms of anxiety are blocking of the mind, tend to blame others, disruption of concentration, attention disorder, confusion, forgetfulness, daydreaming, aware of physiological symptoms, decreased ability to learn, and decreased ability to solve problems; 4) Physiological namely: Trembling, increasing body temperature (Sulistiowati, Septiadi, \& Nopriani, 2017), perspiration, increased tension, trembling sounds, tremors, hand and facial tremors.

Teenagers are a developmental stage that begins at puberty from the age of 13-20 years (DeLaune \& Ladner, 2011). The teen age range according to Santrock (2007), around starting from 10-13 years and ending at the age of 18-22 years.

These developments will have an impact on social problems that can increase the risk of social health disasters in rural areas. Adolescent personality development reaches its peak to the formation of ego identity that will affect self-acceptance and ability to function in society well (Stanhope \& Lancaster, 2004). The psychosocial development of adolescents according to Erikson is in the phase of identity vs. role confusion. This phase will work well if the phase of psychosocial development in the previous phase has passed well (Prayoga, Nursalam, \& Has, 2016). The form of personal identity of adolescents depends on how they respond to their social environment (Jafri \& Ovari, 2015). This identity formation when teenagers choose or determine social variations to be identified and synthesized with their condition. This identity formation will process as long as teenagers live their lives (Nicolson \& Ayers, 2004).

Adolescent life events have an impact on life events (life events) that determine the life of adolescence and determine life in the 
next period (Dwijayanti \& Herdiana, 2011). Social health problems in adolescents who are not well maintained will lead to a disaster in the form of social conflict that can threaten the lives and livelihoods of the community. Adolescent social health disaster is a disaster in the form of behavioral problems that have an impact on social health due to the problem of social interaction in adolescents with their environment.

The conditions of individualistic social interaction make social control very loose which is considered by teenagers as a set of freedom rules. Social interaction with family and peers contributes to adolescents in maintaining their health. Social interaction is intended as a reciprocal influence between individuals with groups in adolescent efforts to solve the problems expected and in the efforts of adolescents to achieve their goals (Ahmadi, 2009).

The social environment of adolescents includes peers, communities and schools. Schools have a very big influence for teenagers, because in addition to home, school is the second environment where many teenagers do various activities and establish social relationships with their friends (Sarwono, 2013).

The problem of social interaction is the insufficiency or excess quantity or ineffectiveness of the quality of social exchanges in adolescents which are characterized by the following characteristics (Nanda International, 2012): 1) Discomfort in social situations, 2) Disfunction of interactions with others, 3) Family reports about changes in style/interaction patterns, 4) Inability to communicate a satisfying sense of social attachment, and 5) Use of ineffective social interaction behavior.

\section{CONCLUSIONS}

The conclusion of this study is that there is no significant relationship between social media addiction, anxiety and social health disaster risk variables in adolescents. Social media access can have negative and positive impacts. Anxiety events and the risk of social health disasters are thought to be influenced by external factors.

Suggestions for educational institutions is the need to maximize social media as a means of interaction with students so that learning can reduce the negative impacts that can cause anxiety and risk of social health disasters.

Other researchers can develop research similar to this research by using other variables in the form of effects of social media addiction and or factors that cause anxiety problems and risk to social health disasters.

Nurses in public health services can make the results of this study as data considerations in an effort to prevent the occurrence of social media addiction, anxiety, and social interaction health disorders.

\section{ACKNOWLEDGMENT}

I would like to thank the AINEC (The Association of Indonesian Nurse Education Center) that grant fund in supporting the implementation of this research.

\section{REFERENCES}

Aarseth, E., Bean, A. M., Boonen, H., Colder Carras, M., Coulson, M., Das, D., ... \& Haagsma, M. C. (2017). Scholars' open debate paper on the World Health Organization ICD-11 Gaming Disorder proposal. Journal of Behavioral Addictions, 6(3), 267270.

Ahmadi, A. (2009). Psikologi Sosial. Jakarta : Rineka Cipta.

Akter, T. (2014). Social Media Addiction, Resistance, and Influence of Awareness: Measurement of Psychology Student's Resistence to Facebook Addiction, Volume 5, no 8. Journal of Social Sciences. Gime American University/ Northern Cyprus.

Andreassen, S, C. (2012). Development Of A Facebook Addiction Scale. Journal Psychological of Science. University Of Bergen

Anggreni, D. Natosba, J. \& Trilia, (2015). Intervention of "Healthy Menstruation" Packet to Dysmenorhea Intensity in Patra Mandiri 1 High School Palembang. Jurnal INJEC Vol. 2 No. 2 Oktober 2015: 162-170

Buente, W., \& Robbin, A. (2008). Trends in Internet information behavior, 20002004. Journal of the Association for 
Information Science and Technology, 59(11), 1743-1760.

DeLaune, S.C., \& Ladner, P.K. (2011) Fundamental of nursing: standarts and practice. (4th ed). New York: Delmar.

Dharma, K.K. (2011). Metodologi Penelitian Keperawatan: Panduan Melaksanakan Dan Menerapkan Hasil Penelitian. Jakarta : Trans Info Media.

Dwijayanti, Y.R., \& Herdiana, I. (2011). Perilaku seksual anak jalanan ditinjau dengan Teori Health Belief Model (HBM). INSAN Vol. 13 No 02, Agustus 2011. Fakultas Psikologi Universitas Airlangga Surabaya.

Griffiths, M. D. (2013). Social networking addiction: Emerging themes and issues. Journal of Addiction Research \& Therapy, 4(5).

Hastono, S.P. (2007). Analisa Data Kesehatan. Fakultas Ilmu Kesehatan Masyarakat Universitas Indonesia. Tidak Dipublikasikan.

Isparmo. (2016). Internet. Survei APJII: Data Pengguna Internet Indonesia Tahun 2016. Diakses pada tanggal 13 Januari 2018

Jafri, Y., \& Ovari, I. (2015). Socialization Stimulation Progression with Socialization Development on Pre School Children Age $36-47$ months. Jurnal INJEC Vol. 2 No. 2 Oktober 2015: 198-204

Mark, G., Iqbal, S., Czerwinski, M., \& Johns, P. (2014, February). Capturing the mood: facebook and face-to-face encounters in the workplace. In Proceedings of the 17th ACM conference on Computer supported cooperative work \& social computing (pp. 1082-1094). ACM.

Mattick, R. P., \& Clarke, J. C. (1998). "Development and validation of measures of social phobia scrutiny fear and social interaction anxiety". Behaviour Research and Therapy, 36,455-470

Muflih, Hamzah, \& Puniawan, W.A. (2017). Penggunaan Smartphone Dan Interaksi Sosial Pada Remaja di SMA Negeri I Kalasan Sleman Yogyakarta. Idea Nursing Journal, 8(1), 12-18.
Musofa, Z, D. (2013). Kecanduan Facebook, Fenomena lain Jejaring Sosial Media. Merdeka.Com. Diakses Pada tanggal 13 Januari 2018.

Nicolson, D., \& Ayers H. (2004). Adolescent problems: a practical guide for parents, techers and counsellors. (2nd ed). London: David Fulton Publisher Ltd.

North American Nursing Diagnosis Association. (2012). NANDA Nursing Diagnoses. North American Nursing Diagnosis Association.

Notoatmodjo, S. (2010). Metodologi Penelitian Kesehatan. Jakarta: Pt. Rineke Cipta.

Noviyarto, H. (2010). Pengaruh Perilaku Konsumen Mobile Internet Terhadap Keputusan Pembelian Paket Layanan Data Unlimited Internet CDMA di DKI Jakarta. InComTech, 1(2), 107129.

Papalia, D.E., Old, S.W., \& Feldman, R.D. (2011). Human development (psikologi perkembangan). (Edisi Ke-9). Jakarta: Kencana.

Polit, D.F., \& Beck, C.T. (2012). Essentila Of Nursing Research: Methodes, Appraisal, And Utilization. (7th Ed). Philadelphia : Lippincott.

Pratikta, A, C. (2013). Efektifitas Problem Solving Training Untuk Mereduksi Kecendrungan Adiksi Situs Jejaring Sosial Pada Peserta Didik. Doctoral dissertation. Bandung: Universitas Pendidikan Indonesia

Prawoto, Y. B. (2010). Hubungan Antara Konsep Diri Dengan Kecemasan Sosial pada Remaja Kelas XI SMA Kristen 2 Surakarta. Doctoral dissertation. Surakarta: Universitas Sebelas Maret.

Prayoga, D.H., Nursalam, \& Has, E.M.M. (2016). Parent Nurture Model in Shaping Behavior of Adolescence 12-15 Ages. Jurnal INJEC Vol. 1 No. 2 Desember 2016: 155-164

Rodiyah \& Praningsih, S. (2015). The Provison Of Orientation To The Anxiety Levels Of The New Patient At The Ponek (Obgyn) General Hospital Jombang. Jurnal INJEC Vol. 2 No. 1 April 2015: 88-91

Santrock, J.W. (2007). Adolesence (Remaja). (Edisi ke-11). Terjemahan oleh 
Soedjarwo. Jakarta: Penerbit Erlangga.

Sarwono, S.W. (2013). Psikologi Remaja. Jakarta : Rajawali Pers.

Siswanto, T. (2013). Optomalisasi sosial media sebagai media pemasaran usaha kecil menengah. Jurnal Liquidity, 2(1), 80-86.

Siswatibudi, H., Paramastri, D. D. I., \& Lazuardi, D. L. (2016). Facebook Messenger Sebagai Media Promosi Kesehatan Reproduksi Remaja Studi Di Smp Muhammadiyah Depok Sleman Yogyakarta. Doctoral dissertation. Yogyakarta:Universitas Gadjah Mada.

Stanhope, M. \& Lancaster, J. (2004). Community \& public health nursing. (6th ed). St Louis: Mosby.

Sugiyono. (2012). Statistika Untuk Penelitian. Cetakan Ke-16. Bandung : Alvabeta.

Sulistiowati, N.M.D., Septiadi, W.N., \& Nopriani, L.P. (2017). Anxiety Level
Analysis Of Nursing Student Who Took Objective Structured Clinical Examination (Osce) Using Face Temperature Distribution Based On Thermal Imaging. Jurnal INJEC, Vol. 2 No.1 Juni 2017: 44-46.

Utari, D. I. (2012). Gambaran Tingkat Kecemasan Pada Warga Binaan Wanita Menjelang Bebas Di Lembaga Pemasyarakatan Wanita Klas Ii A Bandung. Students $e$ Journal, 1(1), 33.

Walker, M. (2013). The good, the bad, and the unexpected consequences of selfie obsession. TeenVogue. com, 201308.

Wangi, K.Y.W., Istianah, \& Alviani, N. (2015). Over Protective Parenting with Adolescents Coping Strategies. Jurnal INJEC Vol. 2 No. 2 Oktober 2015: 217-222.

Widodo, S. T. M. (2015). Facebook sebagai Sumber Belajar. Jurnal Teknodika, l(1). 